\title{
EVALUATION OF WATER POLLUTION STATUS IN SIRET HYDROGRAPHICAL BASIN (SUCEAVA REGION) DUE TO AGRICULTURAL ACTIVITIES
}

\author{
Carmen Zaharia

\begin{abstract}
"Gheorghe Asachi” Technical University of Iasi, Faculty of Chemical Engineering and Environmental Protection,
\end{abstract} \\ Department of Environmental Engineering and Management, 73, Prof. dr. docent D. Mangeron, Iasi 700050, Romania \\ e-mail: czah@ch.tuiasi.ro or czaharia2003@yahoo.com; phone: (+40 232) 278683 ext 2175; fax:( +40 232) 271311
}

\begin{abstract}
The study presents data concerning the water pollution status of Siret hydrographical basin (i.e. surface and ground waters, lakes) in Suceava County area (different controlling/monitoring sections) due to agricultural productive activities, especially regarding some quality indicators (nitrogen-based nutrient concentrations) evaluated for 2008. The real water pollution state in Siret hydrographical basin (Suceava region) is estimated by the global pollution index $\left(I_{G P}^{*}\right)$, and corresponds to values of 1.234 - 1.523 for ground waters, 1.330 - 1.550 for surface water, and $1.330-1.435$ for lakes based on collected data from representative water regulator authority of Siret River hydrographical basin. These values are indicating an aquatic environment modified by agricultural activities within admissible limits. The results of simple risk estimation are also summarized, being found minor referring to ammonia, nitrates and nitrites. These data are recommending the necessity of continuous monitoring of water quality in the Siret River hydrographical basin, in all existing control sections, for identification of any pollution episodes, non-reported by polluters to the local environmental regulators.
\end{abstract}

Keywords: agricultural activity, nutrient quality indicators, global pollution index $\left(I_{G P}^{*}\right)$, real pollution status, Siret River, Suceava County area.

\section{Introduction}

Due to increasing environmental quality constraints and necessity of serious and more complicating natural water treatment for different purposes (mainly because presence of more and more diverse and complex polluting species), the control or monitoring of natural water resources in the whole hydrographical basins are becoming more important, together with its global evaluation of pollution status. Why? Because of necessity to sustainably develop and manage the natural water resources in their hydrographical basins [1-4] which is a complex, multidimensional phenomenon (more than triple dimensions - economical, social and environmental [5], in terms of multiple scales, domains and generations), with a breadth and depth that cannot be fully covered by the current portfolio of reductionist-oriented tools, needing at least triple (or multiple)-quantitatively assessment scale tools [6]. Most specialists/observers recognized that sustainability can be achieved not only by simple application of existing environmental laws to new polluting and developing or conservation problems, or by making incremental changes in those laws, but also by preparation of simple or complex/integrated local environmental impact reports for decisions to reduce or avoid impacts whenever feasible, or local responsibility/awareness to limit different emissions, discharges or evacuations in environment, application of good working practices in different domains to reduce and/or control environmental pollution, application of environmental integrated management scheme, local risk assessments and monitoring measures, or others.

Some of important categories of economical activities are those from agricultural field, and in all over the world it is recognized the existence, in some states, of aggressive and/or urban sustainable agriculture systems [7]. The positive and/or negative impact and risk of these agricultural activities to environment pollution, especially natural water resources pollution, must be always considered in condition of fresh water deficit or drought [5]. Moreover, there are significant computational challenges in integrated sustainability assessment (ISA) for design of policies, regulations and business practices for sustainable agricultural development [7]. Thus, there are proposed different types of assessments [6]: (i) a step-wise procedure that links the science with application of integrated sustainability assessment step by step; (ii) assessment based on development of holistic metrics (toolkit), methods and tools in a way that reflects stakeholder values, allowing key decision-makers to identify the most appropriate for their own projects and to combine the results based on their values (framework described by multi-criteria, systems perspective and engagement of relevant stakeholders). The majority of these assessments are based on computational tools, more and more complicated and dependent on level dimensions, domains, generations and interrelationships between them. Therefore, sometimes the certification of some realities in agricultural systems concluded some disagreements between modeled predicted agricultural development and the real agricultural developing system status, and important also it is the fact that environmental domain (environment conservation) is the key issue in proposing developing system with or without financial or social or other kind of supporting domains. This is the reason for why the environmental impact assessment caused by the agricultural development in the studied Romanian region is estimated by the global pollution 
index $\left(I_{G P}^{*}\right)$, and also the water quality expressed by a quality index $\left(E Q_{w}\right)$, meaning scientific environmental analysis (e.g., physical, chemical analysis of environmental components).

This is one of the paper targets which are evaluating the whole agricultural activities in 2008 in order to follow the development strategy adopted by the local decision-makers and environmental authorities, considering environmental protection requirements in context of regional agricultural, social and environmental development strategy, precisely sustainable development strategy. Moreover, the water resource management is involving permanent monitoring actions concerning analysis of water quality (i.e. supervision, operational, or investigation monitoring depending of water bodies' importance) in different important hydrological basins of Romanian watercourses (e.g., in Moldova zone: Prut, Siret, Bistrita, etc.) [1-4], together with impact diagnosis against local aquatic environment pollution status due to local economic (agricultural, industrial, commercial, among others) and domestic activities included for sustainable development of investigated Romanian region.

The environmental impact assessment still remains one of the first stages in evaluation of sustainability of strategic development plan/program achieved at individual/mixed levels in a specific region. Therefore, the paper focuses on evaluation some reported data of water regional regulating authority (National Agency 'Romanian Waters' Co. - Siret Waters' Division, in Romanian: A.N. Apele Romane - Directia Apelor Siret) in terms of pollution status of Siret River hydrographical basin in Suceava region (i.e. ground waters - 12 control sections, 52 drilling wells; surface waters - 14 control sections; lakes - 5 control sections), and impact assessment of whole agricultural activities by the global pollution index (average value) in different strategic/control sections/domains for elucidation of real pollution status in the Siret hydrographical basin (Suceava region) towards aquatic life forms (as the most sensible pollution receptors) not abiotic solid media.

\section{Experimental}

\section{Siret River Hydrographical Basin: Characterization and Controlling Sections}

Siret River $(15,157 \mathrm{~km}$ length, on Romanian territory) springs from Carpathian mountains of Northern Bucovina (altitude of $1,238 \mathrm{~m}$ from the sea level), in Ukraine (679 $\mathrm{km}$ length), and is considered as the most important influent of Danube River (nearly Galati town), having an average multiannual flow of about $250 \mathrm{~m}^{3} / \mathrm{s}$ and as the biggest hydrological basin from Romanian territory [2].

The surface water resources of Siret hydrological basin (Siret H.B.) represent about $17 \%$ of the total volume of water resources of Romania (i.e. $28,116 \mathrm{~km}^{2}$, with length of $10,280 \mathrm{~km}$, average density of $0.37 \mathrm{~km} / \mathrm{km}^{2}$ ), and are constituted, in principal, of Siret River and its influents (i.e. right side: Siretul Mic, Suceava, Moldova, Bistrita, Trotus, Putna, Buzau, and left side: Polocin and Barlad), together with its natural and accumulation lakes (32 lakes, with an useful volume of $1,847.63 \mathrm{mil} . \mathrm{m}^{3}$ ). The total estimated volume of natural water of Siret H.B. is of $6,868 \mathrm{mil}^{3} \mathrm{~m}^{3}$ from which: 5,800 mil. $\mathrm{m}^{3}$ - surface waters, and $1,068 \mathrm{mil} . \mathrm{m}^{3}$ - ground waters, deserving more than 2,500,867 inhabitants $(39.6 \%$ in urban area) $[2,8]$.

The water quality of Siret River is periodically monitoring by A.N. Apele Romane Company - Siret Waters Sector, by analysing some groups of quality indicators daily, weekly, or monthly $(\mathrm{pH}$; oxygen regime: dissolved oxygen, $\mathrm{COD}-\mathrm{Mn} / \mathrm{CCO}-\mathrm{Cr}, \mathrm{BOD}_{5}$; mineralization level: fixed residues; nutrients'content: ammonia- $\mathrm{NH}_{4}{ }_{4}$, nitrates- $\mathrm{NO}_{2}^{-}$, nitrites$\mathrm{NO}_{2}$, etc.).

The location of control sections from where were periodically sampling water for local or laboratory analysis (PE or glass plastic recipients of 0.5 or $2 \mathrm{dm}^{3}$ capacity, refrigerated or preserved/conserved samples) are [8-10]: (1) Siret River - surface water: 14 control sections organized in areas with significant agricultural activities (i.e. Siret, MihoveniSuceava, Vorniceni-Somuzu Mare, Gura Humorului-Moldova, Carlibaba-Bistrita, Dorna, Sadau, Strujinoasa-Putnisoara, Satu Mare-Pozen, Ostra-Brateasa, Stulpicani-Suha, Gainesti-Ciumarni, Crucea-Barnarel, Gura Negri-Neagra); water lakes: 5 control sections (i.e. natural lake: Lala, accumulation lakes: Rogojesti, Dragomirna, Bucecea, Solca), and ground waters: 12 control sections (i.e. Gramesti, Radauti, Darmanesti, Fantanele, Vicov, Dolhasca, Somuz, Campulung Moldovenesc, Poiana Stampei, Saru Dornei). For appreciation of water quality in 2008, there were mediated the average results registered for seasonal period (at least ten samples collected and analyzed monthly from each control section), these mediated values being considered further for assessment of environmental impact due to agricultural activities.

\section{Materials and Methods}

The laboratory analyses of some physical-chemical indicators, which very well-defined the significant impact of agricultural activities such as $\mathrm{pH}$ and nitrogen-based nutrients content, were performed according with Romanian standard methods internationally approved (SR ISO and/or SR EN), as well as the reference materials, chemical reagents, and operating parameters for spectrophotometer methodology used [11-12]: $\mathrm{pH}$ (SR ISO 10523-97); nitrates- $\mathrm{NO}_{3}^{-}$( $\mathrm{SR}^{-}$ ISO 7890-1:1998, SR ISO 7890-2/3:2000), nitrites- $\mathrm{NO}_{2}^{-}$(SR EN 26777: 2002), ammonia (STAS 6328-85 or SR ISO 7150-1/2001), total nitrogen (SR EN ISO 13395:2002). The values of investigated physical-chemical indicators were given at request by A.N. Apele Romane - Directia Ape Siret, Bacau) $[8,9]$. 


\section{Environmental impact assessment methodology}

There were calculated the water quality index, $E Q_{i}(E q .(1))[13,14]$, and also the evaluation score, $E S_{i}$, expressed by marks between 1 and 10 attributed based on evaluation scale presented in Table 1 [16-18].

$E Q_{i}=C_{i, \text { measured }} / M A C_{i}$

where: $i$ - identification of the specific quality indicator; $C_{i, \text { measured }}-$ measured/analyzed value of the quality indicator, and $M A C_{i}$ - maximum admissible concentration of the quality indicator in accordance with the imposed limits of local environmental legislation or local water regulating authority.

Table 1

\section{Correlation scale of quality index $\left(E Q_{i}\right)$ with evaluation score $\left(E S_{i}\right)$ and effects of pollution level on each} environmental component (quality index scale) $[13,14]$.

\begin{tabular}{|c|c|c|}
\hline $\begin{array}{l}\text { Evaluation } \\
\text { score, } E S_{i}\end{array}$ & $\begin{array}{l}\text { Quality index, } \\
E Q_{i}\end{array}$ & Effects on the aquatic environment and human health \\
\hline 10 & 0 & $\begin{array}{c}\text { The aquatic environment is not affected by the agricultural activity. } \\
\text { Environment state: natural. }\end{array}$ \\
\hline 9 & $0.0-0.2$ & $\begin{array}{l}\text { The aquatic environment is affected by the agricultural activity. The effect } \\
\text { cannot be quantified. }\end{array}$ \\
\hline 8 & $0.2-0.7$ & $\begin{array}{l}\text { The aquatic environment is affected, but under the maximum admissible } \\
\text { limits - level 1. Alert level: potential effects. }\end{array}$ \\
\hline 7 & $0.7-1.0$ & $\begin{array}{c}\text { The aquatic environment is affected, but into maximum admissible limits - } \\
\text { level 2. Intervention level: potential effects. }\end{array}$ \\
\hline 6 & $1.0-2.0$ & $\begin{array}{c}\text { The aquatic environment is affected, over the maximum admissible limits - } \\
\text { level } 1 \text {. The effects are pronounced. }\end{array}$ \\
\hline 5 & $2.0-4.0$ & $\begin{array}{l}\text { The aquatic environment is affected, over the maximum admissible limits - } \\
\text { level } 2 \text {. The effects are harmful. }\end{array}$ \\
\hline 4 & $4.0-8.0$ & $\begin{array}{c}\text { The aquatic environment is affected, over the maximum admissible limits - } \\
\text { level } 3 \text {. The harmful effects are pronounced. }\end{array}$ \\
\hline 3 & $8.0-12.0$ & $\begin{array}{c}\text { Degraded aquatic environment }- \text { level } 1 \text {. The effects are lethal to the } \\
\text { average exposure. }\end{array}$ \\
\hline 2 & $12.0-20.0$ & $\begin{array}{c}\begin{array}{c}\text { Degraded aquatic environment }- \text { level } 2 . \text { The effects are lethal at short times } \\
\text { of exposure. }\end{array}\end{array}$ \\
\hline 1 & $>20.0$ & The aquatic environment is improper for life. \\
\hline
\end{tabular}

The cumulative effect of different nitrogen-based nutrients is expressed by the average arithmetic value (i.e. $E Q_{\text {water }}$ or $\left.E S_{\text {water }}\right)$ of all nutrient indicators $\left(E Q_{j}\right)$ or evaluation scores $\left(E S_{i}\right)$. The environmental impact is quantified by the global pollution index $\left(I_{G P}^{*}\right)$ (Eq.2), using the alternative assessment methodology proposed by Popa et al. [14].

$I_{G P}^{*}=\frac{S_{i}}{S_{r}}=\frac{100 \cdot n}{E S_{1} \cdot E S_{n}+\sum_{i=1}^{n-1} E S_{i} \cdot E S_{i+1}}=\frac{100}{E S_{w}^{2}}$

where: $S_{i}$ - geometrical surface of non-affected natural state (ideal state of environment, a circle with ray of 10), $S_{r}$ - geometrical surface of real environment state (real state, a circle with ray of $E S_{w}$ ), $n$ - number of investigated quality indicators, $E S_{i}$ - the evaluation score corresponding to $i$ quality indicator, $\overline{E S}_{w}^{2}$ - average value of all values for $\left(E S_{i}\right)\left(E S_{i+1}\right)(\mathrm{i}=1,2, \ldots, \mathrm{n}-1)$ that can finally express the global aquatic environment evaluation score $\left(E S_{w}\right)$ (Figure 1) [13-18].

The correlation between the global pollution index $\left(I_{G P}^{*}\right)$, real state of water in the Siret River hydrographical basin (Suceava region), and real water pollution status is characterized in Table 2 [13-18]. 


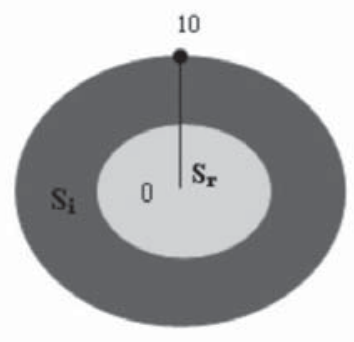

Figure 1. Alternative methodology of global pollution index $\left(I_{G P}^{*}\right)$ : graphical representation $\left(S_{i}\right.$ - ideal state and $S_{r}$ - real state) [13-18].

Correlation in the alternative methodology of global pollution index [13-22].

\begin{tabular}{cc}
\hline$I_{G P}^{*}$ values & Real pollution status of water (e.g., surface water, ground water, lake) \\
\hline $\mathrm{I}_{G P}^{*}=1$ & Natural water, unaffected by all agricultural activities \\
$1<I_{G P}^{*}<2$ & Natural water modified by all agricultural activities in admissible limits \\
$2 \leq I_{G P}^{*} \leq 3$ & Natural water modified by all agricultural activities, with generation of discomfort effects \\
$3 \leq I_{G P}^{*}<4$ & Water modified by all agricultural activities, with stress generation against organisms \\
$4 \leq I_{G P}^{*}<6$ & Natural water modified by all agricultural activities, dangerous for organisms \\
$I_{G P}^{*} \geq 6$ & Polluted natural water (degraded), improper for organisms \\
\hline
\end{tabular}

\section{Results and discussion}

The agricultural activities can directly and indirectly (by infiltration) affect the water quality in a hydrographical basin, e.g. Siret River hydrographical basin, in a specific region (e.g., Suceava region). The contamination level must be estimated in order to implement urgent remediation and control measures or environmental risk assessment.

The vulnerable zones to pollution with nitrates from agricultural activities in Siret River H.B. were established after evaluation of 203 localities (towns and villages, total ground of 10,527.33 $\mathrm{km}^{2}$ ) from (1) Siret Superior (168 locations, $8,165.69 \mathrm{~km}^{2}$ ) and (2) Siret Inferior (35 locations, 2,361.64 $\mathrm{km}^{2}$ ), being found 54 perimeters (mainly actual pollution sources, total 50,293 ha, with 33,094 ha of agricultural area) from which: 18 (villages) in Suceava county, 11 (villages) in Iasi county, 15 (villages) in Neamt county, and 10 (villages) in Bacau county.

The natural polluting sources are due to (1) precipitations (nitrogen oxides from atmosphere emitted by a flash of lightning, fuel combustion, or washing of rocks or ashes from uncontrolled vegetation burning etc. and introduced in natural water resources; (2) ammonia nitrification by nitrosomonas and nitrosococcus microorganisms (bacteria) and of nitrites by nitrobacter; (3) spring source as result of in-deep dissolution in rocks or nitrates-containing soil erosion etc.

The diffuse anthropogenic pollution sources with decreasing in-time significance in overall water pollution status (Suceava county area) are consisting of: (1) wrong fertilization (in excess) with fertilizer (chemical commercial products) and manure (natural product) or compost (Table 3) [8, 9]; (2) non respecting of some important rules of portioning and construction of stables and wells; (3) wrong/poor management of stable refuses (directly storage on soil, animal wastes and wastewaters from zootechnical sector, e.g., horned cattle, swine, fowls, sheep, not corresponding treated or untreated); (4) wrong/poor management of rural municipal wastes; (5) infiltrations of wastewaters produced from unstable tight-closing systems or individual toilets, or inexistence of functional rural wastewater collection and treatment systems.

Table 3

Evolution of fertilizers consumption in Suceava county area (2004-2008) [8, 9].

\begin{tabular}{cccccc}
\hline Fertilizer & \multicolumn{5}{c}{ Consumption of fertilizers, kg/ha } \\
\cline { 2 - 6 } types & 2004 & 2005 & 2006 & 2007 & 2008 \\
\hline Nitrogen-based & 69 & 70 & 72 & 80 & 51 \\
Phosphorus-based & 45 & 55 & 59 & 52 & 50 \\
Potassium-based & 41 & 6 & 71 & 52 & 40 \\
Total & 96 & 64 & 69 & 67 & 48 \\
\hline
\end{tabular}

The mediated monitoring data in 2008 of Siret River hydrographical basin quality, in vulnerable zones to water pollution by nitrogen-based nutrient contents consisting in 12 control sections were presented in Table 4, and the calculated values of water quality indexes $\left(E Q_{i}\right)$ and estimated values from compliance scale of evaluation scores $\left(E S_{i}\right)$ in Table 5.

The measured/analyzed values of ammonia content in Siret River in Suceava region in all 14 control sections were varied between 0.148 and $0.971 \mathrm{mg} / \mathrm{L} \mathrm{NH}_{4}^{+}$, the highest ammonia value being registered at Satu Mare control 
section, and the lowest one at Carlibaba, five (i.e. Siret, Mihoveni, Vorniceni, Gura Humorului, and Satu Mare) of all control sections having surpassing the maximum admissible concentration (MAC). Therefore, the Siret River is affected by ammonia from agricultural activities but in admissible limits with potential effects that require measures for alert or intervention level (corresponding to $E S_{i}$ values of 7-9), but sometimes the effects are pronounced exceeding the admissible limits (values of $E S_{i}=6$ ).

Table 4

Mediated/average values of nitrogen-based nutrient content in Siret River H.B. in Suceava county area (2008) in zones with significant agricultural activities

(authorized statistic data, A.N. Apele Romane - Siret Waters Division [9]).

\begin{tabular}{|c|c|c|c|c|c|c|c|}
\hline \multirow{3}{*}{ No. } & \multirow{3}{*}{$\begin{array}{l}\text { Control section (mixing area } \\
\text { with influents of Siret River) }\end{array}$} & \multicolumn{6}{|c|}{ Analyzed quality indicators, $\mathrm{mg} / \mathrm{L}$} \\
\hline & & \multicolumn{2}{|c|}{$\mathrm{NH}_{4}^{+}$} & \multicolumn{2}{|c|}{$\mathrm{NO}_{3}^{-}$} & \multicolumn{2}{|c|}{$\mathrm{NO}_{2}^{-}$} \\
\hline & & Measured & MAC & Measured & MAC & Measured & MAC \\
\hline 1 & Siret (Siret) & 0.729 & 0.5 & 2.953 & 50 & 0.024 & 0.5 \\
\hline 2 & Mihoveni (Suceava) & 0.655 & 0.5 & 3.159 & 50 & 0.033 & 0.5 \\
\hline 3 & Vorniceni (Somuzu Mare) & 0.604 & 0.5 & 2.684 & 50 & 0.029 & 0.5 \\
\hline 4 & Gura Humorului (Moldova) & 0.840 & 0.5 & 2.772 & 50 & 0.020 & 0.5 \\
\hline 5 & Carlibaba (Bistrita) & 0.148 & 0.5 & 0.639 & 50 & 0.014 & 0.5 \\
\hline 6 & Dorna (Dorna) & 0.257 & 0.5 & 1.892 & 50 & 0.019 & 0.5 \\
\hline 7 & Sadau (Sadau) & 0.328 & 0.5 & 0.903 & 50 & 0.011 & 0.5 \\
\hline 8 & Strujinoasa (Putnisoara) & 0.242 & 0.5 & 0.894 & 50 & 0.016 & 0.5 \\
\hline 9 & Satu Mare (Pozen) & 0.971 & 0.5 & 1.758 & 50 & 0.018 & 0.5 \\
\hline 10 & Ostra (Brateasa) & 0.163 & 0.5 & 0.627 & 50 & 0.022 & 0.5 \\
\hline 11 & Stulpicani (Suha) & 0.275 & 0.5 & 0.583 & 50 & 0.017 & 0.5 \\
\hline 12 & Gainesti (Ciumarni) & 0.169 & 0.5 & 0.872 & 50 & 0.004 & 0.5 \\
\hline 13 & Crucea (Barnarel) & 0.231 & 0.5 & 0.787 & 50 & 0.014 & 0.5 \\
\hline 14 & Gura Negri (Neagra) & 0.184 & 0.5 & 0.469 & 50 & 0.008 & 0.5 \\
\hline
\end{tabular}

For nitrates, in Suceava county area, the mediated values had values between 0.469 and $3.159 \mathrm{mg} / \mathrm{L} \mathrm{NO}_{3}^{-}$, the highest being registered at Mihoveni, and the lowest at Gura Negri, no surpassing admissible limits; the Siret River is affected by nitrates from agricultural activities, but in admissible limits and the effect cannot be yet quantified $\left(E S_{i}=9\right)$.

The mediated values for nitrites are varied between 0.004 and $0.033 \mathrm{mg} / \mathrm{L} \mathrm{NO}_{2}^{-}$, the highest being registered at Mihoveni and the lowest at Gainesti, no surpassing admissible limits; the Siret River is affected by nitrites from agricultural activities but in admissible limits and the effect cannot be yet quantified $\left(E S_{i}=9\right)$.

Table 5

Values of $E Q_{i}$ and $E S_{i}$ in Siret River H.B. in Suceava county area (2008) in zones with significant agricultural activities.

\begin{tabular}{|c|c|c|c|c|c|c|c|}
\hline \multirow[t]{3}{*}{ No. } & \multirow{3}{*}{$\begin{array}{l}\text { Control section (mixing area with } \\
\text { influents of Siret River) }\end{array}$} & \multicolumn{6}{|c|}{ Analyzed quality indicators, $\mathrm{mg} / \mathrm{L}$} \\
\hline & & \multicolumn{2}{|c|}{$\mathrm{NH}_{4}^{+}$} & \multicolumn{2}{|c|}{$\mathrm{NO}_{3}^{-}$} & \multicolumn{2}{|c|}{$\mathrm{NO}_{2}^{-}$} \\
\hline & & $E Q_{i}$ & $E S_{i}$ & $E Q_{i}$ & $E S_{i}$ & $E Q_{i}$ & $E S_{i}$ \\
\hline 1 & Siret (Siret) & 1.458 & 6 & 0.059 & 9 & 0.048 & 9 \\
\hline 2 & Mihoveni (Suceava) & 1.31 & 6 & 0.063 & 9 & 0.066 & 9 \\
\hline 3 & Vorniceni (Somuzu Mare) & 1.208 & 6 & 0.053 & 9 & 0.058 & 9 \\
\hline 4 & Gura Humorului (Moldova) & 1.68 & 6 & 0.055 & 9 & 0.040 & 9 \\
\hline 5 & Carlibaba (Bistrita) & 0.296 & 8 & 0.012 & 9 & 0.028 & 9 \\
\hline 6 & Dorna (Dorna) & 0.514 & 8 & 0.037 & 9 & 0.038 & 9 \\
\hline 7 & Sadau (Sadau) & 0.656 & 8 & 0.018 & 9 & 0.022 & 9 \\
\hline 8 & Strujinoasa (Putnisoara) & 0.484 & 8 & 0.017 & 9 & 0.032 & 9 \\
\hline 9 & Satu Mare (Pozen) & 1.942 & 6 & 0.035 & 9 & 0.036 & 9 \\
\hline 10 & Ostra (Brateasa) & 0.326 & 8 & 0.012 & 9 & 0.044 & 9 \\
\hline 11 & Stulpicani (Suha) & 0.56 & 8 & 0.011 & 9 & 0.034 & 9 \\
\hline 12 & Gainesti (Ciumarni) & 0.338 & 8 & 0.017 & 9 & 0.008 & 9 \\
\hline 13 & Crucea (Barnarel) & 0.462 & 8 & 0.015 & 9 & 0.028 & 9 \\
\hline 14 & Gura Negri (Neagra) & 0.368 & 8 & 0.009 & 9 & 0.016 & 9 \\
\hline
\end{tabular}

The application of alternative methodology of environmental impact assessment (EIM) by the global pollution index permits estimation of an aquatic environment of Siret River modified by the agricultural activities in admissible limits with $I_{G P}^{*}$ values of 1.33 or 1.55 (Table 6) according with the collected data of environmental regulator for this zone. 
The mediated monitoring data in 2008 of water quality in lakes ( 5 control sections) from Siret River H.B. concerning the nitrogen-based nutrient content are presented in the Table 7, and the calculated values of water quality indexes $\left(E Q_{i}\right)$ and estimated values from compliance scale of evaluation scores $\left(E S_{\mathrm{i}}\right)$ in the Table 8.

Table 6 Values of evaluation scores $\left(E S_{i}\right)$, global pollution indexes $\left(I_{G P}^{*}\right)$ and water pollution status of Siret River H.B. in zones with significant agricultural activities.

\begin{tabular}{ccccccccc}
\hline Control Sections & $\overline{E S}_{1}^{2}$ & $E S_{i}$ & $I_{G P}^{*}$ & Control sections & $\overline{E S}_{1}^{2}$ & $E S_{i}$ & $I_{G P}^{*}$ & $\begin{array}{c}\text { Real pollution } \\
\text { status }\end{array}$ \\
\hline Siret & 64.5 & 8.031 & 1.550 & Strujinoasa & 75.166 & 8.669 & 1.330 & $\underline{1.330-1.550}$ \\
Mihoveni & 64.5 & 8.031 & 1.550 & Satu Mare & 64.5 & 8.031 & 1.550 & Water (Siret River) \\
Vorniceni & 64.5 & 8.031 & 1.550 & Ostra & 75.166 & 8.669 & 1.330 & quality modified \\
Gura Humorului & 64.5 & 8.031 & 1.550 & Stulpicani & 75.166 & 8.669 & 1.330 & quall agricultural \\
Carlibaba & 75.166 & 8.669 & 1.330 & Gainesti & 75.166 & 8.669 & 1.330 & by all activities in \\
Dorna & 75.166 & 8.669 & 1.330 & Crucea & 75.166 & 8.669 & 1.330 & admissible limits \\
Sadau & 75.166 & 8.669 & 1.330 & Gura Negri & 75.166 & 8.669 & 1.330 & admision \\
\hline
\end{tabular}

In Suceava county area, the lakes from Siret River H.B. were evaluated (in 2008) by the authorized regulator (A.N. Apele Romane - Siret Waters Division) as containing ammonia between 0.189 and $0.379 \mathrm{mg} / \mathrm{L} \mathrm{NH}_{4}^{+}$(e.g., the highest ammonia value being registered in Rogosesti lake, and the lowest one in Solca lake; no surpassing admissible limits; the lakes are affected by ammonia from agricultural activities but in admissible limits and the effect are pronounced requiring measures for alert or intervention level $\left(E S_{i}=7-8\right)$, nitrites between 0.529 and $0.894 \mathrm{mg} / \mathrm{L} \mathrm{NO}_{3}^{-}(\mathrm{e} . \mathrm{g}$., the highest nitrites value being registered in Dragomirna lake, and the lowest one in Bucecea lake; no surpassing admissible limits; the lakes are affected by nitrates from agricultural activities but in admissible limits and the effect cannot be yet quantified $\left(E S_{i}=9\right)$, and nitrites between 0.010 and $0.019 \mathrm{mg} / \mathrm{L} \mathrm{NO}_{2}^{-}(\mathrm{e} . \mathrm{g}$., the highest nitrites value being registered in Dragomirna lake, and the lowest one in Lala lake; no surpassing admissible limits; the lakes are affected by nitrites from agricultural activities but in admissible limits and the effect cannot be yet quantified $\left(E S_{i}=9\right)$, respectively.

Table 7

Mediated/average values of nitrogen-based nutrient content in lakes from Siret River H.B. in Suceava county area (2008) around zones with significant agricultural activities (authorized statistic data, A.N. Apele Romane - Siret Waters Division [9]).

\begin{tabular}{|c|c|c|c|c|c|c|c|c|}
\hline \multirow{3}{*}{ No. } & \multirow{3}{*}{ Lake } & \multirow{3}{*}{ Type } & \multicolumn{6}{|c|}{ Analyzed quality indicators, $\mathrm{mg} / \mathrm{L}$} \\
\hline & & & \multicolumn{2}{|c|}{$\mathrm{NH}_{4}^{+}$} & \multicolumn{2}{|c|}{$\mathrm{NO}_{3}^{-}$} & \multicolumn{2}{|c|}{$\mathrm{NO}_{2}^{-}$} \\
\hline & & & Measured & MAC & Measured & MAC & Measured & MAC \\
\hline 1 & Lala & natural & 0.256 & 0.5 & 0.746 & 50 & 0.010 & 0.5 \\
\hline 2 & Rogojesti & accumulation & 0.303 & 0.5 & 0.538 & 50 & 0.012 & 0.5 \\
\hline 3 & Dragomirna & accumulation & 0.379 & 0.5 & 0.894 & 50 & 0.019 & 0.5 \\
\hline 4 & Bucecea & accumulation & 0.264 & 0.5 & 0.529 & 50 & 0.011 & 0.5 \\
\hline 5 & Solca & accumulation & 0.189 & 0.5 & 0.629 & 50 & 0.017 & 0.5 \\
\hline
\end{tabular}

Values of $E Q_{i}$ and $E S_{i}$ in lakes from Siret River H.B. in Suceava county area (2008) around zones with significant agricultural activities.

\begin{tabular}{|c|c|c|c|c|c|c|c|c|}
\hline \multirow[t]{3}{*}{ No. } & \multirow[t]{3}{*}{ Lake } & \multirow[t]{3}{*}{ Type } & \multicolumn{6}{|c|}{ Analyzed quality indicators, $\mathrm{mg} / \mathrm{L}$} \\
\hline & & & \multicolumn{2}{|c|}{$\mathrm{NH}_{4}^{+}$} & \multicolumn{2}{|c|}{$\mathrm{NO}_{3}^{-}$} & \multicolumn{2}{|c|}{$\mathrm{NO}_{2}^{-}$} \\
\hline & & & $E Q_{i}$ & $E S_{i}$ & $E Q_{i}$ & $E S_{i}$ & $E Q_{i}$ & $E S_{i}$ \\
\hline 1 & Lala & natural & 0.512 & 8 & 0.014 & 9 & 0.020 & 9 \\
\hline 2 & Rogojesti & accumulation & 0.606 & 8 & 0.010 & 9 & 0.024 & 9 \\
\hline 3 & Dragomirna & accumulation & 0.758 & 7 & 0.017 & 9 & 0.038 & 9 \\
\hline 4 & Bucecea & accumulation & 0.528 & 8 & 0.010 & 9 & 0.022 & 9 \\
\hline 5 & Solca & accumulation & 0.378 & 8 & 0.012 & 9 & 0.034 & 9 \\
\hline
\end{tabular}

The application of alternative methodology of environmental impact assessment by the global pollution index permits estimation of an aquatic environment of lakes in Siret River H.B. modified by the agricultural activities in admissible limits with $I_{G P}^{*}$ values of 1.33 or 1.435 (Table 9) according with the collected data of water regulator authority (A.N. Apele Romane - Siret Waters Division) for this zone (Suceava county area). 
The mediated monitoring data in 2008 (May-August) of ground water quality in 12 control drilling wells from Siret River H.B. (Suceava, Somuz, Moldova, Dorna, Neagra Sarului) concerning the nitrogen-based nutrient content are presented in Table 10, and the calculated values of water quality indexes $\left(E Q_{i}\right)$ and estimated values from compliance scale of evaluation scores $\left(E S_{i}\right)$ in the Table 11.

Table 9

Values of evaluation scores $\left(E S_{i}\right)$, global pollution indexes $\left(I_{G P}^{*}\right)$ and water pollution status of lakes in Siret River H.B. around zones with significant agricultural activities.

\begin{tabular}{ccccccrrc}
\hline Lakes & $\overline{E S}_{1}^{2}$ & $E S_{i}$ & $I_{G P}^{*}$ & $\begin{array}{c}\text { Control } \\
\text { sections }\end{array}$ & $\overline{E S}_{1}^{2}$ & $E S_{i}$ & $I_{G P}^{*}$ & Real pollution status \\
\hline Lala & 75.166 & 8.669 & 1.330 & Bucecea & 75.166 & 8.669 & 1.330 & $\begin{array}{c}\text { Lakes modified by all } \\
\text { agricultural activities in } \\
\text { admissible limits }\end{array}$ \\
Rogojesti & 75.166 & 8.669 & 1.330 & Solca & 75.166 & 8.669 & 1.330 & \\
Dragomirna & 69.666 & 8.346 & 1.435 & & & & & admisim
\end{tabular}

In Suceava county area, the ground waters from Siret River H.B. (Suceava county area) were evaluated (in 2008) by the water authorized regulator (A.N. Apele Romane - Siret Waters Division) as containing ammonia between 0.00 and $6.05 \mathrm{mg} / \mathrm{L} \mathrm{NH}_{4}^{+}$(e.g., the highest ammonia value being registered in F1 drilling well of Poiana Stampei control section, and the lowest one in Saru Dornei (F2-F5) control section; no surpassing admissible limits; the ground waters are not affected by ammonia from agricultural activities), nitrites between 0.45 and $21.47 \mathrm{mg} / \mathrm{L} \mathrm{NO}_{3}^{-}$(e.g., the highest nitrites value being registered in Campulung Moldovenesc-Moldova drilling wells, and the lowest one in DolhascaSomuz drilling wells; no surpassing admissible limits; the ground waters are not affected by nitrates from agricultural activities), and nitrites between 0.000 and $0.069 \mathrm{mg} / \mathrm{L} \mathrm{NO}_{2}^{-}$(e.g., the highest nitrites value being registered in Fantanele drilling wells, and the lowest one in Berchisesti-Moldova drilling wells; no surpassing admissible limits; the ground waters are not affected by nitrites from agricultural activities), respectively.

Table 10

Mediated/average values of nitrogen-based nutrient content in ground waters (control drilling wells) from Siret River H.B. in Suceava county area (2008) in zones with significant agricultural activities (authorized statistic data, A.N. Apele Romane - Siret Waters Division [9]).

\begin{tabular}{|c|c|c|c|c|c|c|c|c|c|c|}
\hline \multirow[t]{3}{*}{ No. } & \multirow[t]{3}{*}{ Control section } & \multirow{3}{*}{$\begin{array}{c}\text { Drilling } \\
\text { wells } \\
\text { no. }\end{array}$} & \multirow{3}{*}{$\begin{array}{l}\text { Coll- } \\
\text { ection } \\
\text { data }\end{array}$} & \multirow[t]{3}{*}{$\mathrm{pH}$} & \multicolumn{6}{|c|}{ Analyzed quality indicators, mg/L } \\
\hline & & & & & \multicolumn{2}{|c|}{$\mathrm{NH}_{4}^{+}$} & \multicolumn{2}{|c|}{$\mathrm{NO}_{3}^{-}$} & \multicolumn{2}{|c|}{$\mathrm{NO}_{2}^{-}$} \\
\hline & & & & & Measured & MAC & Measured & MAC & Measured & MAC \\
\hline \multirow[t]{4}{*}{1} & Gramesti - Suceava & F3 & 30.05 & 7.49 & 0.15 & 0.5 & 1.85 & 50 & 0.040 & 0.5 \\
\hline & & F2 & 08.07 & 6.83 & 0.31 & 0.5 & 1.91 & 50 & 0.044 & 0.5 \\
\hline & & F4 & 30.05 & 6.88 & 0.08 & 0.5 & 15.01 & 50 & 0.013 & 0.5 \\
\hline & & F5 & 08.07 & 6.79 & 0.25 & 0.5 & 8.49 & 50 & 0.022 & 0.5 \\
\hline \multirow[t]{6}{*}{2} & Radauti - Suceava & F6 & 03.06 & 7.04 & 0.11 & 0.5 & 0.62 & 50 & 0.0016 & 0.5 \\
\hline & & F6 & 17.11 & 7.24 & 0.09 & 0.5 & 1.07 & 50 & 0.153 & 0.5 \\
\hline & & F7 & 03.06 & 7.28 & 0.09 & 0.5 & 5.67 & 50 & 0.026 & 0.5 \\
\hline & & F7 & 17.11 & 6.91 & 0.06 & 0.5 & 4.00 & 50 & 0.025 & 0.5 \\
\hline & & F17 & 03.06 & 7.30 & 0.09 & 0.5 & 6.50 & 50 & 0.019 & 0.5 \\
\hline & & F17 & 17.11 & 7.14 & 0.03 & 0.5 & 5.76 & 50 & 0.022 & 0.5 \\
\hline \multirow[t]{4}{*}{3} & Darmanesti - & F2 & 26.05 & 6.68 & 0.03 & 0.5 & 2.15 & 50 & 0.010 & 0.5 \\
\hline & Suceava & $\mathrm{F} 2$ & 17.11 & 7.09 & 0.31 & 0.5 & 0.48 & 50 & 0.014 & 0.5 \\
\hline & & F4 & 26.05 & 6.69 & 0.51 & 0.5 & 3.47 & 50 & 0.010 & 0.5 \\
\hline & & F4 & 17.11 & 7.16 & 0.31 & 0.5 & 4.53 & 50 & 0.039 & 0.5 \\
\hline \multirow[t]{4}{*}{4} & Fantanele - & F6 & 24.05 & 7.28 & 0.17 & 0.5 & 0.77 & 50 & 0.069 & 0.5 \\
\hline & Suceava & F6 & 15.11 & 6.80 & 3.45 & 0.5 & 10.52 & 50 & 0.022 & 0.5 \\
\hline & & F8 & 24.05 & 6.85 & 0.15 & 0.5 & 2.56 & 50 & 0.037 & 0.5 \\
\hline & & F8 & 15.11 & 6.96 & 0.92 & 0.5 & 1.98 & 50 & 0.012 & 0.5 \\
\hline \multirow[t]{4}{*}{5} & Vicov - Suceava & F4 & 03.06 & 7.40 & 0.09 & 0.5 & 0.73 & 50 & 0.11 & 0.5 \\
\hline & & F4 & 17.11 & 7.46 & 0.09 & 0.5 & 1.82 & 50 & 0.019 & 0.5 \\
\hline & & F5 & 03.06 & 7.11 & 0.09 & 0.5 & 0.89 & 50 & 0.004 & 0.5 \\
\hline & & F5 & 17.11 & 7.30 & 0.01 & 0.5 & 6.48 & 50 & 0.024 & 0.5 \\
\hline \multirow[t]{3}{*}{6} & Dolhasca - Somuz & F3 & 15.07 & 7.26 & 0.17 & 0.5 & 0.45 & 50 & 0.002 & 0.5 \\
\hline & & F3 & 01.12 & 7.24 & 0.29 & 0.5 & 5.99 & 50 & 0.17 & 0.5 \\
\hline & & F3 & 01.12 & 7.13 & 0.12 & 0.5 & 5.79 & 50 & 0.007 & 0.5 \\
\hline
\end{tabular}


Table 10 (Continuation)

\begin{tabular}{|c|c|c|c|c|c|c|c|c|c|c|}
\hline \multirow{3}{*}{ No. } & \multirow{3}{*}{ Control section } & \multirow{3}{*}{$\begin{array}{c}\text { Drilling } \\
\text { wells } \\
\text { no. }\end{array}$} & \multirow{3}{*}{$\begin{array}{l}\text { Coll- } \\
\text { ection } \\
\text { data }\end{array}$} & \multirow{3}{*}{$\mathrm{pH}$} & \multicolumn{6}{|c|}{ Analyzed quality indicators, $\mathrm{mg} / \mathrm{L}$} \\
\hline & & & & & \multicolumn{2}{|c|}{$\mathrm{NH}_{4}^{+}$} & \multicolumn{2}{|c|}{$\mathrm{NO}_{3}^{-}$} & \multicolumn{2}{|c|}{$\mathrm{NO}_{2}^{-}$} \\
\hline & & & & & Measured & MAC & Measured & MAC & Measured & MAC \\
\hline \multirow[t]{4}{*}{7} & Somuz - Somuz & F2 & 15.07 & 7.80 & 0.19 & 0.5 & 12.28 & 50 & 0.018 & 0.5 \\
\hline & & $\mathrm{F} 2$ & 01.12 & 7.11 & 0.13 & 0.5 & 11.16 & 50 & 0.004 & 0.5 \\
\hline & & F3 & 15.07 & 7.50 & 0.15 & 0.5 & 3.08 & 50 & 0.046 & 0.5 \\
\hline & & F3 & 01.12 & 7.13 & 0.12 & 0.5 & 5.79 & 50 & 0.007 & 0.5 \\
\hline \multirow[t]{4}{*}{8} & Campulung & F2 & 31.05 & 7.93 & 0.03 & 0.5 & 20.94 & 50 & 0.015 & 0.5 \\
\hline & Moldovenesc - & F2 & 30.11 & 6.79 & 0.06 & 0.5 & 4.59 & 50 & 0.008 & 0.5 \\
\hline & Moldova & F3 & 31.05 & 7.82 & 0.05 & 0.5 & 21.47 & 50 & 0.024 & 0.5 \\
\hline & & F3 & 30.11 & 6,76 & 0.08 & 0.5 & 4.33 & 50 & 0.019 & 0.5 \\
\hline \multirow[t]{5}{*}{9} & Berchisesti - & F3 & 03.06 & 7.16 & 0.10 & 0.5 & 8.21 & 50 & 0.066 & 0.5 \\
\hline & Moldova & F3 & 30.11 & 7.33 & 0.26 & 0.5 & 7.12 & 50 & 0.000 & 0.5 \\
\hline & & F4 & 03.06 & 6.46 & 0.09 & 0.5 & 4.96 & 50 & 0.020 & 0.5 \\
\hline & & F7 & 03.06 & 6.74 & 0.08 & 0.5 & 11.12 & 50 & 0.020 & 0.5 \\
\hline & & F7 & 30.11 & 7.27 & 0.67 & 0.5 & 7.71 & 50 & 0.000 & 0.5 \\
\hline \multirow[t]{4}{*}{10} & Bogdanesti - & F3 & 21.05 & 7.58 & 0.08 & 0.5 & 7.71 & 50 & 0.003 & 0.5 \\
\hline & Moldova & F3 & 17.11 & 7.18 & 0.03 & 0.5 & 2.38 & 50 & 0.004 & 0.5 \\
\hline & & F4 & 21.05 & 7.43 & 0.09 & 0.5 & 3.06 & 50 & 0.003 & 0.5 \\
\hline & & $\mathrm{F} 4$ & 17.11 & 7.18 & 0.05 & 0.5 & 1.79 & 50 & 0.009 & 0.5 \\
\hline \multirow[t]{4}{*}{11} & Poiana Stampei - & F1 & 14.09 & 6.42 & 0.00 & 0.5 & 6.07 & 50 & 0.020 & 0.5 \\
\hline & Dorna & F1 & 12.10 & 6.30 & 6.05 & 0.5 & 0.69 & 50 & 0.041 & 0.5 \\
\hline & & F2 & 14.09 & 6.21 & 0.00 & 0.5 & 1.38 & 50 & 0.006 & 0.5 \\
\hline & & F2 & 12.10 & 6.14 & 0.10 & 0.5 & 0.60 & 50 & 0.017 & 0.5 \\
\hline \multirow[t]{6}{*}{12} & Saru Dornei- & $\mathrm{F} 2$ & 14.09 & 6.46 & 0.00 & 0.5 & 1.26 & 50 & 0.009 & 0.5 \\
\hline & Neagra Sarului & $\mathrm{F} 2$ & 12.10 & 6.28 & 0.17 & 0.5 & 0.60 & 50 & 0.011 & 0.5 \\
\hline & & F5 & 14.09 & 6.30 & 0.00 & 0.5 & 1.26 & 50 & 0.017 & 0.5 \\
\hline & & F3 & 12.10 & 6.42 & 2.93 & 0.5 & 1.32 & 50 & 0.023 & 0.5 \\
\hline & & F4 & 14.09 & 6.11 & 0.00 & 0.5 & 1.20 & 50 & 0.012 & 0.5 \\
\hline & & F4 & 12.10 & 6.42 & 0.14 & 0.5 & 0.80 & 50 & 0.035 & 0.5 \\
\hline
\end{tabular}

The application of alternative methodology of environmental impact assessment by the global pollution index permits estimation of an aquatic environment of ground waters from control drilling wells of Siret River H.B. not modified by the agricultural activities with $I_{G P}^{*}$ values between 1.234 and 1.523 (Table 12) according with the collected data of authorized water regulator/controller for this zone (Suceava county area).

The results of simple environmental risk estimation (Risk = Probability $x$ Gravity) for these relatively low nitrogen-based nutrients values (ammonia, nitrate and nitrite) indicated minor polluting risk (Risk $\leq 2)$.

Table 11

Values of $E Q_{i}$ and $E S_{i}$ in ground waters (control drilling wells) from Siret River H.B. in Suceava county area (2008) in zones with significant agricultural activities

(authorized statistic data, A.N. Apele Romane - Siret Waters Division [9]).

\begin{tabular}{|c|c|c|c|c|c|c|c|c|c|}
\hline \multirow{3}{*}{ No. } & \multirow{3}{*}{ Control section } & \multirow{3}{*}{$\begin{array}{c}\text { Drilling } \\
\text { wells } \\
\text { no. }\end{array}$} & \multirow{3}{*}{$\begin{array}{l}\text { Collec- } \\
\text { tion data }\end{array}$} & \multicolumn{6}{|c|}{ Analyzed quality indicators, $\mathrm{mg} / \mathrm{L}$} \\
\hline & & & & \multicolumn{2}{|c|}{$\mathrm{NH}_{4}^{+}$} & \multicolumn{2}{|c|}{$\mathrm{NO}_{3}^{-}$} & \multicolumn{2}{|c|}{$\mathrm{NO}_{2}^{-}$} \\
\hline & & & & $E Q_{i}$ & $E S_{i}$ & $E Q_{i}$ & $E S_{i}$ & $E Q_{i}$ & $E S_{i}$ \\
\hline \multirow[t]{5}{*}{1} & Gramesti - & F3 & 30.05 & 0.30 & 8 & 0.037 & 9 & 0.08 & 9 \\
\hline & Suceava & $\mathrm{F} 2$ & 08.07 & 0.62 & 8 & 0.038 & 9 & 0.088 & 9 \\
\hline & & F4 & 30.05 & 0.16 & 9 & 0.300 & 8 & 0.026 & 9 \\
\hline & & F5 & 08.07 & 0.50 & 8 & 0.169 & 9 & 0.044 & 9 \\
\hline & & & Average & 0.395 & 8.25 & 0.136 & 8.75 & 0.059 & 9 \\
\hline \multirow[t]{7}{*}{2} & Radauti - & F6 & 03.06 & 0.22 & 8 & 0.012 & 9 & 0.032 & 9 \\
\hline & Suceava & F6 & 17.11 & 0.18 & 9 & 0.021 & 9 & 0.306 & 8 \\
\hline & & F7 & 03.06 & 0.18 & 9 & 0.113 & 9 & 0.052 & 9 \\
\hline & & F7 & 17.11 & 0.12 & 9 & 0.08 & 9 & 0.05 & 9 \\
\hline & & F17 & 03.06 & 0.18 & 9 & 0.13 & 9 & 0.038 & 9 \\
\hline & & F17 & 17.11 & 0.06 & 9 & 0.115 & 9 & 0.044 & 9 \\
\hline & & & Average & 0.157 & 8.83 & 0.078 & 9 & 0.087 & 8.83 \\
\hline
\end{tabular}


Table 11 (Continuation)

\begin{tabular}{|c|c|c|c|c|c|c|c|c|c|}
\hline \multirow[t]{3}{*}{ No. } & \multirow[t]{3}{*}{ Control section } & \multirow{3}{*}{$\begin{array}{c}\text { Drilling } \\
\text { wells } \\
\text { no. }\end{array}$} & \multirow{3}{*}{$\begin{array}{l}\text { Collec- } \\
\text { tion data }\end{array}$} & \multicolumn{6}{|c|}{ Analyzed quality indicators, $\mathrm{mg} / \mathrm{L}$} \\
\hline & & & & \multicolumn{2}{|c|}{$\mathrm{NH}_{4}^{+}$} & \multicolumn{2}{|c|}{$\mathrm{NO}_{3}^{-}$} & \multicolumn{2}{|c|}{$\mathrm{NO}_{2}^{-}$} \\
\hline & & & & $E Q_{i}$ & $E S_{i}$ & $E Q_{i}$ & $E S_{i}$ & $E Q_{i}$ & $E S_{i}$ \\
\hline \multirow[t]{5}{*}{3} & Darmanesti - & $\mathrm{F} 2$ & 26.05 & 0.60 & 8 & 0.043 & 9 & 0.02 & 9 \\
\hline & Suceava & $\mathrm{F} 2$ & 17.11 & 0.62 & 8 & 0.009 & 9 & 0.028 & 9 \\
\hline & & F4 & 26.05 & 1.02 & 6 & 0.069 & 9 & 0.02 & 9 \\
\hline & & F4 & 17.11 & 0.62 & 8 & 0.90 & 9 & 0.078 & 9 \\
\hline & & & Average & 0.715 & 7.50 & 0.255 & 9 & 0.036 & 9 \\
\hline \multirow[t]{5}{*}{4} & Fantanele - & F6 & 24.05 & 0.34 & 8 & 0.015 & 9 & 0.138 & 9 \\
\hline & Suceava & F6 & 15.11 & 6.9 & 4 & 0.210 & 8 & 0.044 & 9 \\
\hline & & F8 & 24.05 & 0.30 & 8 & 0.051 & 9 & 0.074 & 9 \\
\hline & & F8 & 15.11 & 1.84 & 6 & 0.039 & 9 & 0.024 & 9 \\
\hline & & & Average & 2.345 & $6 / 50$ & 0.078 & 8.75 & 0.070 & 9 \\
\hline \multirow[t]{5}{*}{5} & Vicov - Suceava & F4 & 03.06 & 0.18 & 9 & 0.014 & 9 & 0.022 & 9 \\
\hline & & F4 & 17.11 & 0.18 & 9 & 0.036 & 9 & 0.038 & 9 \\
\hline & & F5 & 03.06 & 0.18 & 9 & 0.017 & 9 & 0.008 & 9 \\
\hline & & F5 & 17.11 & 0.02 & 9 & 0.129 & 9 & 0.048 & 9 \\
\hline & & & Average & 0.14 & 9 & 0.049 & 9 & 0.029 & 9 \\
\hline \multirow[t]{4}{*}{6} & Dolhasca - & F3 & 15.07 & 0.34 & 8 & 0.009 & 9 & 0.004 & 9 \\
\hline & Somuz & F3 & 01.12 & 0.58 & 8 & 0.199 & 9 & 0.034 & 9 \\
\hline & & F4 & 01.12 & 1.34 & 6 & 0.051 & 9 & 0.014 & 9 \\
\hline & & & Average & 0.753 & 7.33 & 0.086 & 9 & 0.017 & 9 \\
\hline \multirow[t]{5}{*}{7} & Somuz - Somuz & F2 & 15.07 & 0.38 & 8 & 0.245 & 8 & 0.036 & 9 \\
\hline & & F2 & 01.12 & 0.26 & 8 & 0.223 & 8 & 0.008 & 9 \\
\hline & & F3 & 15.07 & 0.30 & 8 & 0.061 & 9 & 0.092 & 9 \\
\hline & & F3 & 01.12 & 0.24 & 8 & 0.115 & 9 & 0.014 & 9 \\
\hline & & & Average & 0.295 & 8 & 0.161 & 8.50 & 0.037 & 9 \\
\hline \multirow[t]{5}{*}{8} & Campulung & $\mathrm{F} 2$ & 31.05 & 0.06 & 9 & 0.418 & 8 & 0.03 & 9 \\
\hline & Moldovenesc - & $\mathrm{F} 2$ & 30.11 & 0.12 & 9 & 0.091 & 9 & 0.016 & 9 \\
\hline & Moldova & $\mathrm{F} 3$ & 31.05 & 0.10 & 9 & 0.429 & 8 & 0.048 & 9 \\
\hline & & F3 & 30.11 & 0.16 & 9 & 0.086 & 9 & 0.038 & 9 \\
\hline & & & Average & 0.11 & 9 & 0.256 & 8.50 & 0.033 & 9 \\
\hline \multirow[t]{6}{*}{9} & Berchisesti - & F3 & 03.06 & 0.20 & 9 & 0.164 & 9 & 0.132 & 9 \\
\hline & Moldova & F3 & 30.11 & 0.52 & 8 & 0.142 & 9 & 0 & 10 \\
\hline & & $\mathrm{F} 4$ & 03.06 & 0.18 & 9 & 0.099 & 9 & 0.04 & 9 \\
\hline & & F7 & 03.06 & 0.16 & 9 & 0.222 & 8 & 0.04 & 9 \\
\hline & & F7 & 30.11 & 0.16 & 9 & 0.222 & 8 & 0.04 & 9 \\
\hline & & & Average & 0.48 & 8.20 & 0.156 & 8.80 & 0.042 & 9.40 \\
\hline \multirow[t]{5}{*}{10} & Bogdanesti - & F3 & 21.05 & 0.16 & 9 & 0.047 & 9 & 0.006 & 9 \\
\hline & Moldova & F3 & 17.11 & 0.06 & 9 & 0.061 & 9 & 0.08 & 9 \\
\hline & & F4 & 21.05 & 0.18 & 9 & 0.035 & 9 & 0.006 & 9 \\
\hline & & F4 & 17.11 & 0.10 & 9 & 0.074 & 9 & 0.018 & 9 \\
\hline & & & Average & 0.125 & 9 & 0.054 & 9 & 0.009 & 9 \\
\hline \multirow[t]{5}{*}{11} & Poiana Stampei - & F1 & 14.09 & 0 & 10 & 0.121 & 9 & 0.040 & 9 \\
\hline & Dorna & $\mathrm{F} 1$ & 12.10 & 12.1 & 2 & 0.013 & 9 & 0.082 & 9 \\
\hline & & F2 & 14.09 & 0 & 10 & 0.027 & 9 & 0.012 & 9 \\
\hline & & $\mathrm{F} 2$ & 12.10 & 0.20 & 9 & 0.012 & 9 & 0.034 & 9 \\
\hline & & & Average & 3.075 & 7.75 & 0.043 & 9 & 0.042 & 9 \\
\hline 12 & Saru Dornei - & F2 & 14.09 & 0 & 10 & 0.025 & 9 & 0.018 & 9 \\
\hline & Neagra Sarului & F2 & 12.10 & 0.34 & 8 & 0.012 & 9 & 0.022 & 9 \\
\hline & & F5 & 14.09 & 0 & 10 & 0.025 & 9 & 0.034 & 9 \\
\hline & & F3 & 12.10 & 5.86 & 4 & 0.026 & 9 & 0.046 & 9 \\
\hline & & F4 & 14.09 & 0 & 10 & 0.024 & 9 & 0.024 & 9 \\
\hline & & $\mathrm{F} 4$ & 12.10 & 0.28 & 8 & 0.016 & 9 & 0.07 & 9 \\
\hline & & & Average & 1.08 & 8.33 & 0.021 & 9 & 0.035 & 9 \\
\hline
\end{tabular}


As result of this impact evaluation due to agricultural activities against aquatic environment of Siret River H.B., it is recommended the implementation of preventive protection programme for each agricultural activity and permanent monitoring of nitrogen-based nutrient contents in all existing control sections, for identification of any pollution episodes, non-reported by polluters to the local environmental regulators.

Table 12

Values of evaluation scores $\left(E S_{i}\right)$, global pollution indexes $\left(I_{G P}^{*}\right)$ and water pollution status of ground waters (control drilling wells) from Siret River H.B. in zones with significant agricultural activities.

\begin{tabular}{|c|c|c|c|c|c|c|c|c|}
\hline $\begin{array}{l}\text { Control section } \\
\text { (drilling wells) }\end{array}$ & $\overline{E S}_{1}^{2}$ & $E S_{i}$ & $I_{G P}^{*}$ & Control sections & $\overline{\mathrm{E}}_{1}^{2}$ & $E S_{i}$ & $I_{G P}^{*}$ & $\begin{array}{c}\text { Real pollution } \\
\text { status }\end{array}$ \\
\hline $\begin{array}{l}\text { Gramesti- } \\
\text { Suceava }\end{array}$ & 75.135 & 8,668 & 1.330 & Somuz - Somuz & 72.291 & 8.502 & 1.383 & $\underline{1.234-1.523}$ \\
\hline $\begin{array}{l}\text { Radauti - } \\
\text { Suceava }\end{array}$ & 78.874 & 8.886 & 1.266 & $\begin{array}{l}\text { Campulung } \\
\text { Moldovenesc }\end{array}$ & 78.041 & 8.834 & 1.281 & \multirow{5}{*}{$\begin{array}{c}\text { Ground waters } \\
\text { not modified by } \\
\text { all agricultural } \\
\text { activities }\end{array}$} \\
\hline $\begin{array}{l}\text { Darmanesti - } \\
\text { Suceava }\end{array}$ & 72.375 & 8.507 & 1.381 & Berchisesti & 77.500 & 9.00 & 1.234 & \\
\hline $\begin{array}{c}\text { Fantanele - } \\
\text { Suceava }\end{array}$ & 65.656 & 8.102 & 1.523 & Bogdanesti & 81.000 & 9.00 & 1.234 & \\
\hline Vicov - Suceava & 81.00 & 9.000 & 1.234 & Poiana Stampei & 73.760 & 8.588 & 1.355 & \\
\hline $\begin{array}{c}\text { Dolhasca - } \\
\text { Somuz }\end{array}$ & 71.444 & 8.452 & 1.399 & Saru Dornei & 77.054 & 8.778 & 1.298 & \\
\hline
\end{tabular}

\section{Conclusions}

Some collected data from the authorized water regulator/controller of Siret River hydrographical basin (A.N. Apele Romane $\tilde{n}$ Directia Ape Siret) concerning the nitrogen-based nutrient concentration (i.e. ammonia, nitrates, nitrites) are interpreted in terms of environmental impact quantification due to agricultural activities in Suceava county area. In general, the water pollution status of Siret River hydrographical basin in Suceava county area is in admissible limits $\left(I_{G P}^{*}<1.55\right)$, and the risks are minor as illustrated below.

\begin{tabular}{|c|c|c|c|}
\hline $\begin{array}{l}\text { No. } \\
\text { eval. }\end{array}$ & $\begin{array}{l}\text { Water type from Siret River H.B. } \\
\text { (Suceava county area) }\end{array}$ & $\begin{array}{r}I_{G P}^{*} \text { values } \\
(\min -\max )\end{array}$ & Real pollution status \\
\hline 1 & $\begin{array}{l}\text { Surface water of Siret River in zone of agricultural } \\
\text { polluting sources ( } 14 \text { control sections) }\end{array}$ & $1.330-1.550$ & $\begin{array}{c}\text { Surface water modified by } \\
\text { agricultural activities in admissible } \\
\text { limits }\end{array}$ \\
\hline 2 & $\begin{array}{l}\text { Water from lakes in zone of agricultural polluting } \\
\text { sources ( } 5 \text { control sections) }\end{array}$ & $1.330-1.435$ & $\begin{array}{c}\text { Lakes modified by agricultural } \\
\text { activities in admissible limits }\end{array}$ \\
\hline 3 & $\begin{array}{l}\text { Ground waters in zone of agricultural pollution sources } \\
\text { (12 control sections, } 52 \text { drilling wells) } \\
\text { (Min - Bogdanesti, Vicov and Max - Fantanele) }\end{array}$ & $1.234-1.523$ & $\begin{array}{l}\text { Ground waters modified by } \\
\text { agricultural activities in admissible } \\
\text { limits }\end{array}$ \\
\hline
\end{tabular}

These data indicate the necessity of continuous water monitoring in Siret River hydrographical basin in all investigated control sections for identification of different pollution episodes, non-reported by polluters to the local environmental regulators.

\section{References}

1. Teodosiu, C.; Cojocariu, C.; Musteret, C.P.; Dascalescu, I.G.; Caraene, I. Assessment of Human and Natural Impacts Over Water Quality in the Prut River Basin, Romania. Environmental Engineering and Management Journal, 2010, 8(3), pp. 1439-1450.

2. Zaharia, C.; Radu, I. Control Study of Siret River Quality in Pascani County Area and Estimation of Its Pollution Level. Acta Chemica Iasi, 2013, 21(2), pp. 119-136. DOI: 10.2478/achi-2013-0011.

3. Zaharia, C.; Teslaru, M.I. Control and analysis of some water quality indicators of Bahlui River in Iasi County area (spring season). The Bulletin of the Polytechnic Institute from Iasi, series: Chemistry and Chemical Engineering Section, 2012, LVIII(LXII) (2), pp. 69-79.

4. Danalache, E.; Zaharia, C. Control of some quality indicators of Prut River in two control sections (Radauti and Darabani) (spring season). Scientific papers, series: Horticulture, 2013, 56(2), pp. 531-536. 
5. Zaharia, C. The sustainable agricultural development-concepts, principles, eco-efficiency, eco-equity. Agronomical Research in Moldavia, 2010, vol. XLIII (143), 3, pp. 91-99.

6. Halog, A.; Manik, Y. Advancing Integrated Systems Modelling Framework for Life Cycle Sustainability Assessment. Sustainability, 2011, 3, pp. 469-499. DOI: 10.3390/su3020469.

7. Dernbach, J.C.; Mintz, J.A. Environmental Laws and Sustainability: An Introduction. Sustainability, 2011, 3, pp. 531-540. DOI: 10.3390/su3030531.

8. Siret River Monitoring. http://www.apesiret.usv.ro

9. Tilica, L. Quality and pollution level assessment in waters of Siret River hydrographical basin, Suceava County. Master Dissertation Thesis, 'Gheorghe Asachi' Technical University of Iasi, Romania, 2013, pp. 49-89 (in Romanian).

10. Zaharia, C. Elements of aquatic environment chemistry. Performantica: Iasi, 2011, pp. 45-80 (in Romanian).

11. Surpateanu, M.; Zaharia, C. Environmental chemistry. Manual of practice applications. Rotaprint, Gheorghe Asachi' Technical University Publishing House: Iasi, 1999, pp. 63-92.

12. Surpateanu, M.; Zaharia, C. ABC - Analysis Methods for Control of Environmental Factors. T Press: Iasi, 2002, pp. 63-140.

13. Zaharia, C. Evaluation of environmental impact produced by different economic activities with the global pollution index. Environmental Science and Pollution Research, 2012, 19(6), pp. 2448-2455.

14. Popa, C.; Cojocaru, C.; Macoveanu, M. Geometrical correlation method for global estimation of the ecosystem state. Environmental Engineering and Management Journal, 2005, 4(4), pp. 437-447.

15. Macoveanu, M. Methods and techniques of ecological impact assessment. Ecozone: Iasi, 2nd edition, 2005, pp. 54-88 (in Romanian).

16. Zaharia, C.; Murarasu, I. Environmental impact assessment induced by an industrial unit of basic chemical organic compounds synthesis using the alternative method of global pollution index. Environmental Engineering and Management Journal, 2009, 8(1), pp. 107-112.

17. Zaharia, C. Assessing the impact of some industrial and transport activities on soil by the global pollution index. Environmental Engineering and Management Journal, 2011, 10(3), pp. 387-391.

18. Mocanu, A.M.; Luca, C.; Odochian, L.; Zaharia, C.; Iordache, C. Assessment of environmental impact of some new aryloxyalkyl carboxilic acid derivatives. Environmental Engineering and Management Journal, 2012, 11(2), pp. 413-420. 